\title{
Article \\ Effect of Internal AC Heating on the Temperature Homogeneity of Different Size Battery Cells
}

\author{
Howard Richards (1) and Christopher Vagg * (1) \\ Institute for Advanced Automotive Propulsion Systems (IAAPS), University of Bath, Claverton Down, \\ Bath BA2 7AY, UK; hctr20@bath.ac.uk \\ * Correspondence: crmv20@bath.ac.uk
}

Citation: Richards, H.; Vagg, C. Effect of Internal AC Heating on the Temperature Homogeneity of Different Size Battery Cells. Batteries 2022, 8, 17. https://doi.org/ $10.3390 /$ batteries 8020017

Academic Editor: Pascal Venet

Received: 20 December 2021

Accepted: 8 February 2022

Published: 12 February 2022

Publisher's Note: MDPI stays neutral with regard to jurisdictional claims in published maps and institutional affiliations.

Copyright: () 2022 by the authors. Licensee MDPI, Basel, Switzerland. This article is an open access article distributed under the terms and conditions of the Creative Commons Attribution (CC BY) license (https:/ / creativecommons.org/licenses/by/ $4.0 /)$.

\begin{abstract}
Rapidly warming up batteries is an important challenge both for conventional lithium-ion batteries, which operate best over $15^{\circ} \mathrm{C}$, and for most solid-state batteries, which currently require operating temperatures over $60^{\circ} \mathrm{C}$. Internal heating using an alternating current (AC) has been proposed as a possible solution in automotive applications, with faster heating rates possible than conventional external heating methods. This paper investigates the performance of internal AC heating on cells of different sizes, for both cylindrical and pouch formats. A novel experimental arrangement is used in which two cells are tested in series while connected with opposing polarity to create a zero-voltage string, allowing the use of less expensive testing equipment. The results show that larger cells exhibit a considerably greater distribution of surface temperature than smaller format cells during internal heating. This is likely due to the more extreme spatial variation in current density in the current collectors, causing an uneven distribution of internal heat generation. This highlights a significant difference compared to external heating methods, which are not affected by this, and has important implications for temperature measurement and battery management if this type of internal heating is to be used, since temperature sensors must be placed in hot spots or supplemented by validated models to ensure all parts of the battery stay within safe temperature limits.
\end{abstract}

Keywords: battery; internal heating; temperature homogeneity; temperature distribution; AC

\section{Introduction}

Public pressure is growing on governments and private entities to tackle global warming and the adverse effects it causes on the environment. A prominent example of the changes this pressure is causing is in the automotive industry, with a large shift away from internal combustion engines (ICEs) powered by fossil fuels and towards battery electric vehicles (BEVs) which offer zero tailpipe emissions. This is especially the case in the passenger car market.

Lithium-ion batteries operate best within a relatively narrow operational temperature band of approximately $15-30^{\circ} \mathrm{C}$. Since they generate heat during use, as a result of internal losses, a great deal of literature covers the significant problem of battery cooling to ensure the maximum temperature limit is not exceeded. However, at lower temperatures, their performance is also a point of concern, with both decreased capacity (effective range) and increased degradation (battery longevity) being notable issues [1,2]. These are two highly important issues as they directly affect the environmental footprint [3,4] and consumer confidence in BEVs [5], hindering their uptake. One obvious solution is to heat the battery before use, and studies have shown that even when energy from the battery pack itself is used to heat the battery, the effective range of the BEV can increase due to the associated rise in performance [6].

External heating is currently used in most BEVs, which uses a dedicated heat source (usually a PTC heater) powered either by the battery itself or an external power source, and transfers that heat to the batteries usually by means of a battery thermal management 
system (BTMS). The heat transfer fluid may be air or a liquid circuit, and these sorts of convective and conductive BTMS are generally well understood and easy to implement, hence their widespread adoption. Water systems offer performance advantages over air due to its higher convection coefficient than air (better heat transfer), though liquid systems do introduce more design challenges [7]. External heating systems also add cost and complexity by increasing the parts count, as well as volume and mass [8]. A further important limitation of external heating systems is that the rate of heating which can be achieved is affected by the power rating of the electrical heater and its power supply, the heat transfer coefficients between the fluid and the battery cells, the thermal conductivity of the cells, and battery geometry, which will mean each pack needs a tailored solution. Larger cells, as are increasingly the trend in the automotive sector ( $>100$ Ah in some cases), present a particular difficulty since they are more difficult to heat uniformly and risk having significant thermal gradients through them due to the reduced surface area per unit volume (higher Biot numbers).

Another method which has been the subject of much interest is internal heating, which could be used either to supplement the external air/water heating system and achieve faster heating rates, or possibly to completely replace it along with its associated management systems. In any case, the BTMS would likely need to retain the fluid circulation loop for the purposes of cooling.

Methods of internal heating can be broadly divided into filament heating or active material heating, either of which can be achieved by application of direct current (DC) or alternating current (AC) [7]. In all cases, the current flow through a resistance within the battery cells causes heat generation within the cells. For filament heating, the resistance is a dedicated heating element, usually a nickel foil. This has the advantage of being functionally separate from the active cell materials and thus mitigates the risk of any damage to them; however, it adds some mass, volume and cost to the cells [8]. For active material heating, the resistances within the battery (ohmic, charge transfer, etc.) are exploited to generate heat within it. This method can be applied to cells of conventional construction and so is the focus of this paper. Active material heating using DC has been shown to be highly effective for fast temperature rise, and its control optimised for energy efficiency and heating performance [9,10]; however, it requires large changes in cell state of charge (SOC) amounting to cell cycling, which is achievable when connected to the grid but impractical when an external energy source/sink is unavailable. This paper therefore focusses on internal AC heating, which can be achieved without large changes in SOC.

A considerable advantage of this internal heating, especially for larger format cells, is that it should achieve a much more uniform temperature distribution than external heating, since all of the cell is heated together. However, data supporting this widely held assumption are scarce in the literature. This study aims to investigate the effect of internal $\mathrm{AC}$ heating on the temperature homogeneity of different battery cells.

The remainder of this paper is structured as follows: Section 2 will review the relevant literature, Section 3 describes the experimental methodology used in this study, Section 4 presents results and notably how battery size and format affect the rate of self-heating and temperature homogeneity, Section 5 discusses the relevance of the findings and Section 6 presents the conclusions.

\section{Review of Current Work}

\subsection{Temperature Homogenity}

Internal heating of battery cells is an attractive solution because it offers fast warm up times and good energy efficiency $[7,8]$. One simulation of mutual pulse heating showed batteries could be heated from -20 to $20^{\circ} \mathrm{C}$ within $220 \mathrm{~s}$, whilst only consuming $5 \%$ of the battery energy [6]. Hu et al. [7] reviewed various internal and external heating solutions and found internal heating to be more promising in the long term, particularly the alternating current (AC) and mutual pulse heating methods; however, they noted the need for better understanding of its effects on temperature homogeneity, both at the cell and pack level. 
Temperature homogeneity is important as hot or cold spots can cause a battery thermal management system to misdiagnose the true state of the battery and thus mismanage the cell or pack, causing otherwise avoidable degradation or failure. Internal self-heating is widely considered to offer the potential for very good spatial temperature homogeneity. This is intuitive, since the rate of heat generation per unit volume should be roughly uniform throughout the battery cell; however, there is very little published information to support this presumption. Ruan et al. [11] presented positive results for temperature homogeneity of an 18,650 cylindrical cell undergoing internal ripple current heating, measuring $<1.6^{\circ} \mathrm{C}$ while heating from -15 to $5^{\circ} \mathrm{C}$ in $320 \mathrm{~s}$. Zhu et al. [12] presented results for a 30 Ah prismatic cell, showing cell surface variations were within $2^{\circ} \mathrm{C}$; however, the current was relatively low $(1.3 \mathrm{C})$, resulting in slower heating than many other studies ( -23 to $0{ }^{\circ} \mathrm{C}$ in $30 \mathrm{~min}$ ). Rizk et al. [13] examined the temperature homogeneity of $60 \mathrm{Ah}$ prismatic cells using multiple thermocouples and a thermal camera, however this was for continuous charge-discharge cycling at $1 \mathrm{C}$ with a period over $25 \mathrm{~min}$, achieving an average temperature rise of approximately $10^{\circ} \mathrm{C}$ in $1 \mathrm{~h}$. They observed a surface temperature differential of approximately $2{ }^{\circ} \mathrm{C}$ between the start of the active material near the tabs to the opposite end of the battery. Jiang et al. [14] examined the effect of internal self-heating on the temperature homogeneity of a module of 12 large format pouch cells and reported very good homogeneity between the cells, where the temperature of each was measured at the centre of its large face. However, they did not measure the temperature homogeneity across each cell. More data are required to quantify the achievable heating rate and resulting cell temperature homogeneity using AC internal heating, for different cell types and sizes.

\subsection{Effect on Degradation}

The largest concerns surrounding AC heating of batteries are around the risk of increasing rate of degradation, especially due to charge/discharge at low temperatures or as a result of exceeding the electrochemical limit of the cells (in particular voltage limits at very high or very low SOC). However, many papers have demonstrated that these effects can be mitigated. Ge et al. suggest current limitation to prevent lithium deposition [15], while Jiang et al. combined AC and DC during heating to avoid lithium deposition and saw negligible change in the charge or discharge capacities over 600 cycles [14]. Zhu et al. applied a square wave AC heating signal and found no obvious deterioration of capacity, DC resistance or impedance over hundreds of AC heating cycles, with deterioration only equivalent to calendar aging [12]. Ruan et al. also found no detrimental effect on battery state of health after 30 heating cycles with a sinusoidal current [11].

Other studies have investigated the link between motor inverter ripple and battery degradation, but with varying results. Uddin et al. found capacity fade and impedance rose as the AC frequency rose, and that an AC signal superimposed over a direct current (DC) signal increased battery degradation [16].

\subsection{Heating Circuits}

The circuits used to apply the sinusoidal current to the cells varies from great cost to great complexity. Some used expensive lab equipment such as Ge et al. [15], requiring a high-current potentiostat and 3 terminal cell to take electro impedance spectroscopy measurements of each electrode to find operating parameters. Zhu et al. [12] required a bipolar-type DC supply capable of delivery $80 \mathrm{~A}$ with programmable voltage limits to apply a square wave alternating current to cells.

However, work exists that is of great interest to the practical applications of battery internal heating, and specifically internal self-heating where the only power comes from the battery itself. Shang et al. created a sine-wave alternating current heater from simple components using an uncomplicated control method. The circuit had two inductor-capacitor pairs in an "interleaved-parallel topology" shown in Figure 1, which excites the batteries at the resonant frequency of the LC pairs $[17,18]$. Jiang et al. also designed a method using an 
LC pair and four MOSFETs in a "soft-switching resonance circuit", which enables heating by combining sinusoidal AC and DC [14]. These methods not only enabled effective and fast heating of the batteries without the need for an external power supply or expensive inverters, but also could be controlled relatively trivially.

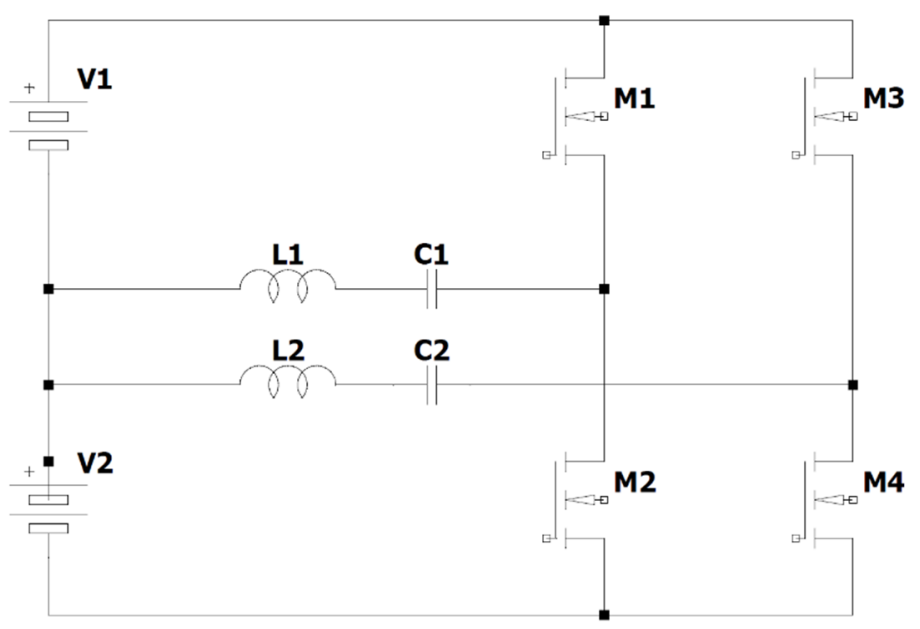

Figure 1. Inter-leaved parallel circuit to internally self-heat two strings of cells by the resonant frequency of the LC pairs, as used by Shang et al. [17].

\section{Experimental Setup}

An experiment was designed to analyse the temperature homogeneity of different types and sizes of battery cells subject to internal heating. The experimental setup is unique because it can be achieved with solely an AC power source. In this case an AC lab supply was used capable of supplying $8.4 \mathrm{~A}$ at up to $500 \mathrm{~Hz}$ (GW Instek APS-7100E), but crucially it does not require the ability to oscillate around a DC offset. This is due to the $0 \mathrm{~V}$ string created by connecting the cells in opposing polarity. This modification reduces the cost of testing and a circuit diagram of the setup is shown in Figure 2.

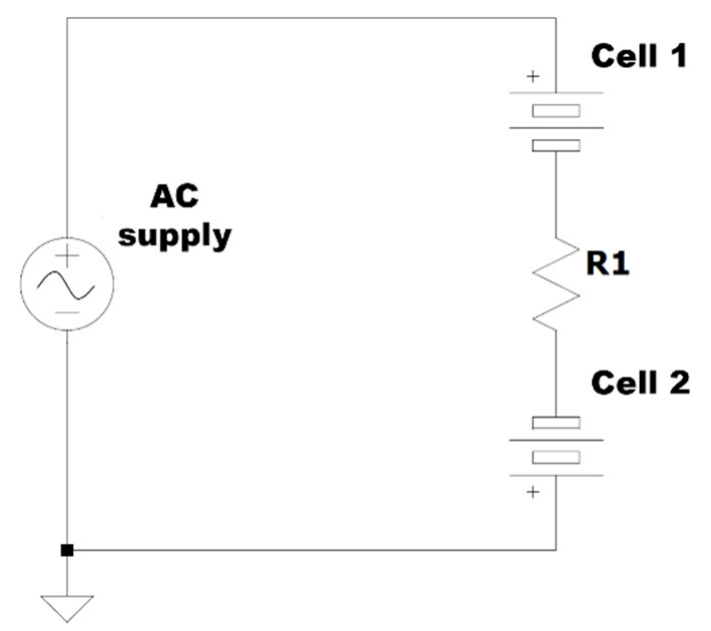

Figure 2. Experimental setup at the University of Bath, featuring the two batteries connected in opposite polarities, with an AC power supply connected across them.

The resistor R1 was added so as the over current protection (OCP) of the supply was not triggered and was also used as a way to visualise the current through the battery using an oscilloscope and confirm the current reading of the AC supply. A $680 \mathrm{~m} \Omega$ power resistor on a heat sink was used for all cells with exception of the $110 \mathrm{mAh}$ DTP Pouch Cell where a second of these resistors was used in series as with only one the voltages required to 
achieve a $2 \mathrm{C}$ current were so small that the supply detected an open circuit and switched off. The oscilloscope was still only connected around the same $680 \mathrm{mOhm}$ resistor as the previous tests, not around both.

Temperatures were measured using T-type thermocouples and associated PicoLogger with 8 channels connected to a laptop. Cell 1 from the layout in Figure 2 had 6 thermocouples fixed to it using thermal epoxy in the layout shown in Figure 3, while the other had one applied to the centre of the battery. A final thermocouple was used to monitor the environmental temperature. Tests were started at $-18^{\circ} \mathrm{C}$ and ended when the maximum cell temperature reached $0^{\circ} \mathrm{C}$, or when thermal equilibrium was reached. The largest pouch cell was allowed to continue slightly beyond $0{ }^{\circ} \mathrm{C}$ in order to reach thermal equilibrium and thus allow better comparison of the effect of size.

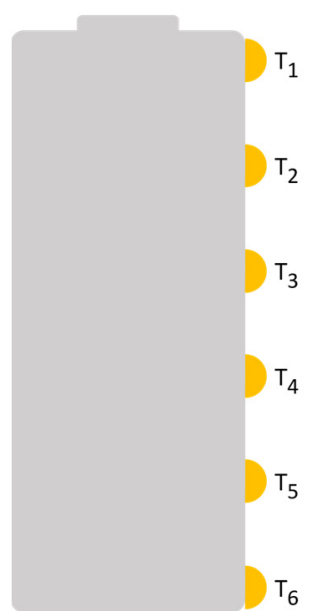

(a)

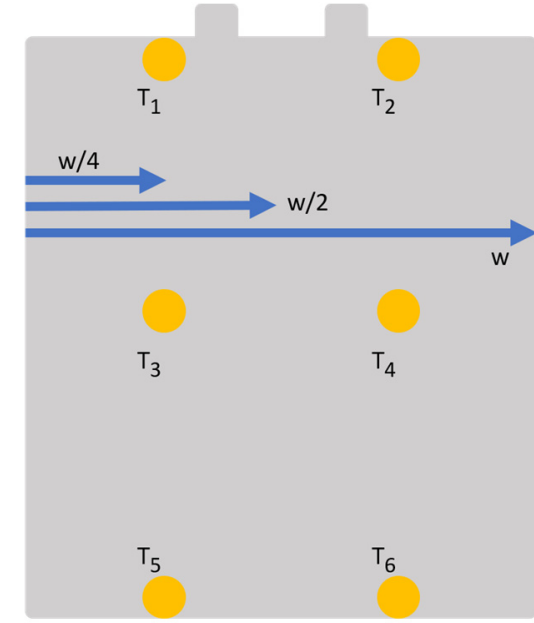

(b)

Figure 3. Layout of thermocouple channels on cell 1 for (a) the cylindrical and (b) the pouch cells. For (a), channels 1 and 6 were at the extremes, with the others evenly spaced along the axial direction. For (b), channels 1 and 2 were nearest the tabs, channel 5 and 6 at far end, and 3 and 4 making up the middle row.

The cells listed in Table 1 were all heated using the experimental setup described. For each pair of cells tested a sinusoidal voltage of frequency $300 \mathrm{~Hz}$ was applied to the cells, to achieve a current equivalent to $2 \mathrm{C}$ at the start of the test. The power supply was used in voltage control (potentiostatic) mode, and so some small drop in current was generally observed during the test as the cell heated and its internal resistance fell.

Table 1. Details and properties of the battery cells used.

\begin{tabular}{cccc}
\hline Cell & Capacity $(\mathbf{m A h})$ & Chemistry & Dimensions $(\mathbf{m m})$ \\
\hline Molicel INR-18650-P26A & 2600 & NMC & Cylindrical: Ø18 $\times 65$ \\
Molicel INR-21700-P42A & 4200 & NMC & Cylindrical: Ø21 $\times 70$ \\
\hline DTP Pouch Cell 2000 mAh & 2000 & LCO & $5 \times 47 \times 62.5$ \\
DTP Pouch Cell 1000 mAh & 1000 & LCO & $5 \times 34 \times 44$ \\
DTP Pouch Cell 110 mAh & 110 & LCO & $3.5 \times 14 \times 21$ \\
\hline
\end{tabular}

\section{Results}

\subsection{Effect of Cell Size on Heating Efficacy and Homogeneity}

The overview of the results for the cylindrical cells is shown in Figure 4, and for the pouch cells in Figure 5. The tests on the two smaller pouch cells (110 and $1000 \mathrm{mAh})$ were terminated before they reached $0{ }^{\circ} \mathrm{C}$ because they reached thermal equilibrium at average cell temperatures of 0.84 and $6.7^{\circ} \mathrm{C}$ over ambient temperature (which could not be precisely controlled), respectively (Figure 5), and would not heat further at this current. 


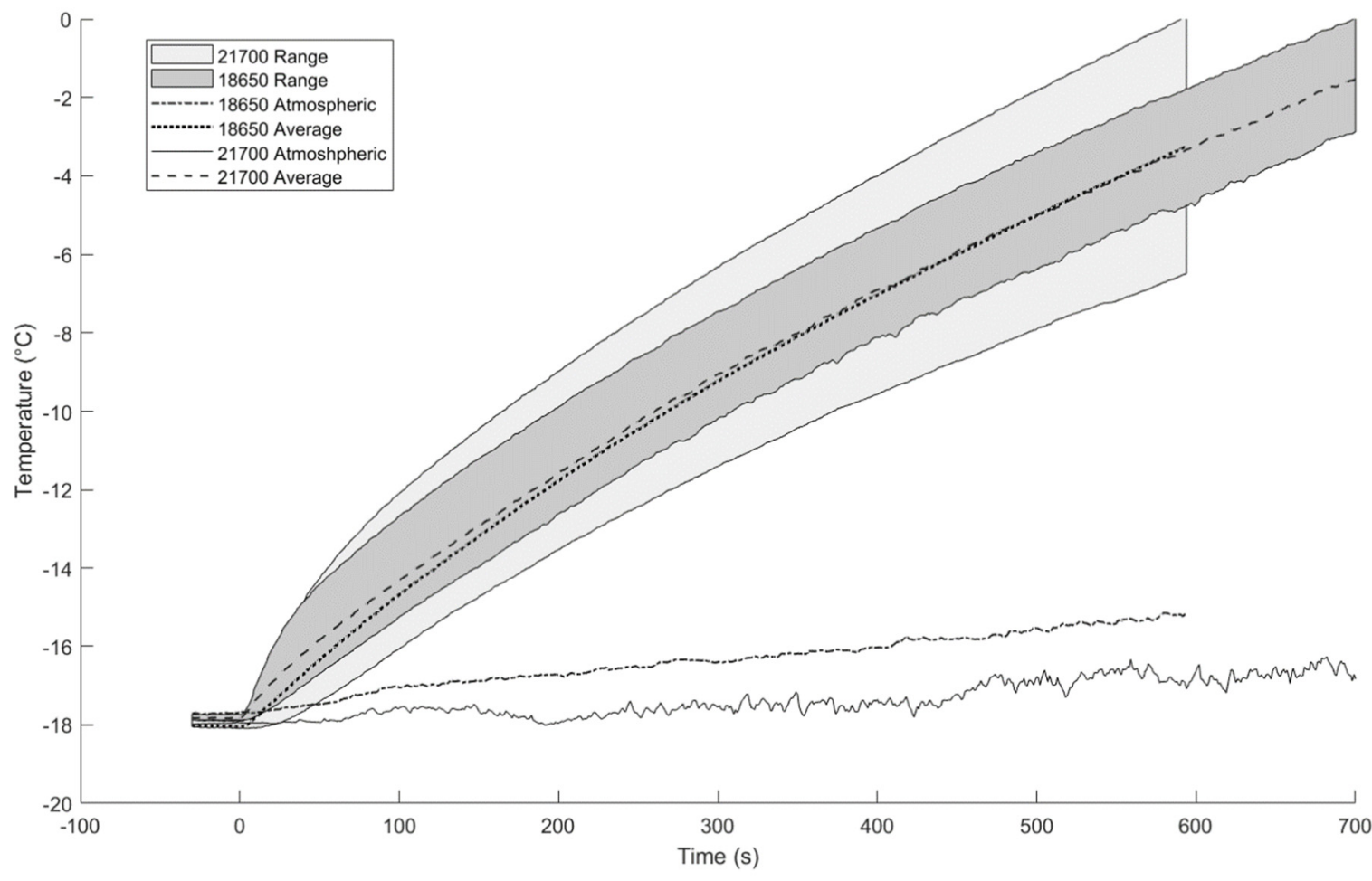

Figure 4. Overview of results for Molicel cylindrical cells. Illustrates average cell surface temperature, range of cell surface temperatures, and atmospheric temperature for each cell.

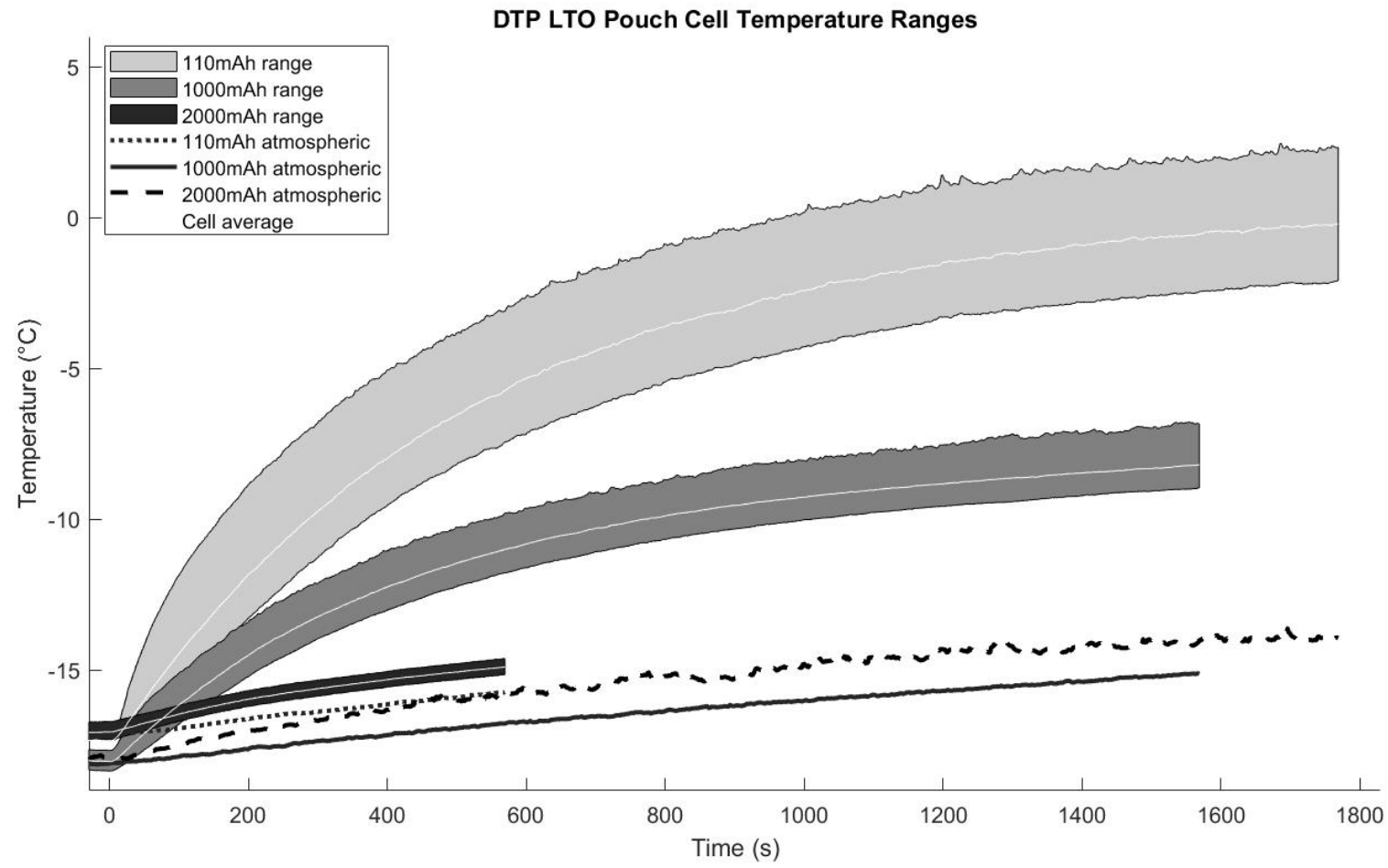

Figure 5. Overview of results for DTP pouch cells. Illustrates average cell surface temperature, range of cell surface temperatures, and atmospheric temperature for each cell.

In terms of the effect of cell size, a notable difference is exhibited between the two types of cell: for the pouch cells, the rate of average temperature rise is considerably affected by the size of the cell, whereas for the cylindrical cells, it is not. Some initial and highly generalisable understanding of this observation can be obtained even without detailed 
knowledge of the cell, such as its impedance: Since the prism always has a higher surface area (SA) than a cylinder of the same volume, the pouch cells have a higher surface-areato-volume ratio $(\mathrm{SA}: \mathrm{V})$. This is further exaggerated by the fact that the pouch cells were of smaller capacity and size, further increasing their SA:V (Table 2). This higher SA:V for the pouch cells explains their generally lower equilibrium temperatures since there is more area for heat loss to the environment relative to the heat generated.

Table 2. Battery cell performance and heat transfer characteristics.

\begin{tabular}{ccccc}
\hline Cell & Capacity (mAh) & $\begin{array}{c}\text { Surface Area: Volume } \\
\left(\mathbf{m m}^{-\mathbf{1}}\right)\end{array}$ & $\begin{array}{c}\text { Impedance @300 Hz }(\boldsymbol{\Omega}) \\
\text { Surface Area }\left(\mathbf{W} / \mathbf{m m}^{\mathbf{2}}\right)\end{array}$ & $\begin{array}{c}\text { Heat Generation: } \\
\text { Suce }\end{array}$ \\
\hline Molicel INR-18650-P26A & 2600 & 0.253 & 0.199 & 1286 \\
Molicel INR-21700-P42A & 4200 & 0.219 & 0.088 & 1169 \\
\hline DTP Pouch Cell 2000 mAh & 2000 & 0.475 & 0.126 & 289 \\
DTP Pouch Cell 1000 mAh & 1000 & 0.504 & 0.169 & 179 \\
DTP Pouch Cell 110 mAh & 110 & 0.810 & 0.309 & 18 \\
\hline
\end{tabular}

Although helpful for some initial insight, the $\mathrm{SA}: \mathrm{V}$ is lacking as a predictor of thermal response because it does not consider the rate of heat generation. By considering the cell impedance at $300 \mathrm{~Hz}$ and calculating the Joule heating we obtain the ratio of heat generation to surface area, HG:SA (Table 2). Here, we see that the two cylindrical cells are very closely matched for HG:SA which is reflected in their almost identical rate of temperature rise (Figure 4). For the pouch cells, the differences in HG:SA also explain the differences in thermal response observed in Figure 5, which are not explained by SA:V alone since this is very similar for the $1000 \mathrm{mAh}$ and $2000 \mathrm{mAh}$ cells.

The consistency of the pouch cell results can be examined further by considering Newton's law of cooling for the thermal equilibrium state,

$$
Q=h A\left(T_{a m b}-T_{b a t t}\right)
$$

where $Q$ is the steady-state heat generation and transfer to surroundings in $\mathrm{W}, h$ is the convective heat transfer coefficient in $\mathrm{W} / \mathrm{m}^{2} \mathrm{~K}, A$ the total surface area of the cell in $\mathrm{m}^{2}$, $T_{a m b}$ the ambient environmental temperature, and $T_{b a t t}$ the average cell surface temperature (average of the 6 measurements). Solving for $h$ yields the results shown in Table 3, which are well within the normal range for free convection in air [19] and the consistency of which confirms that the problem can be scaled and generalised. Thus, the HG:SA ratio is a crucial factor in the rate of heating achievable using internal AC heating.

Table 3. Calculation of convective heat transfer coefficient in thermal equilibrium condition.

\begin{tabular}{|c|c|c|c|c|}
\hline Cell & $\begin{array}{c}\text { Temperature over } \\
\text { Ambient }\left({ }^{\circ} \mathrm{C}\right)\end{array}$ & $\begin{array}{l}\text { Joule Heating } \\
\text { (W) }\end{array}$ & $\begin{array}{l}\text { Surface Area } \\
\left(\mathrm{mm}^{2}\right)\end{array}$ & $\begin{array}{l}\text { Convective Heat Transfer Coefficient, } h \\
\qquad\left(\mathrm{~W} / \mathrm{m}^{2} \mathrm{~K}\right)\end{array}$ \\
\hline Pouch, $2000 \mathrm{mAh}$ & 13.62 & 2.016 & 6970 & 21.2 \\
\hline Pouch, $1000 \mathrm{mAh}$ & 6.68 & 0.676 & 3772 & 26.8 \\
\hline Pouch, $110 \mathrm{mAh}$ & 0.84 & 0.015 & 833 & 21.5 \\
\hline
\end{tabular}

The range of temperatures across each cell (between maximum and minimum cell temperature) increases greatly as the size of the cell increases for both types of cell (Figures 4 and 5). For the 18,650 and 21,700 cylindrical cells variations of 2.88 and $6.54{ }^{\circ} \mathrm{C}$, respectively, are observed at the end of the test. For the 110, 1000 and $2000 \mathrm{mAh}$ pouch cells the variation recorded was $0.55,1.98$, and $4.44{ }^{\circ} \mathrm{C}$, respectively. The larger temperature variation in larger cells is explained, for example, by the greater funnelling of current in the current collectors of large cells, leading to a larger range in current density, and the larger physical dimensions which reduce heat flux, therefore leading to higher temperature differences. 
As the tests progress, the measured atmospheric temperature tends to increase; this is largely due to the sensor having been positioned close to the cells and is therefore affected by the heat they give off.

\subsection{Cell Surface Temperature Profiles}

The evolution of cell surface temperature for the $2000 \mathrm{mAh}$ pouch cell and 18,650 (the two cells of most similar capacity) is shown in Figures 6 and 7, respectively. For the pouch cell, the results show a temperature gradient along the length of the cell, with higher temperatures near to the tabs and the lowest temperatures at the end furthest from the tabs. The general trend is in line with the cell temperature distribution observed from DC cycling [13].

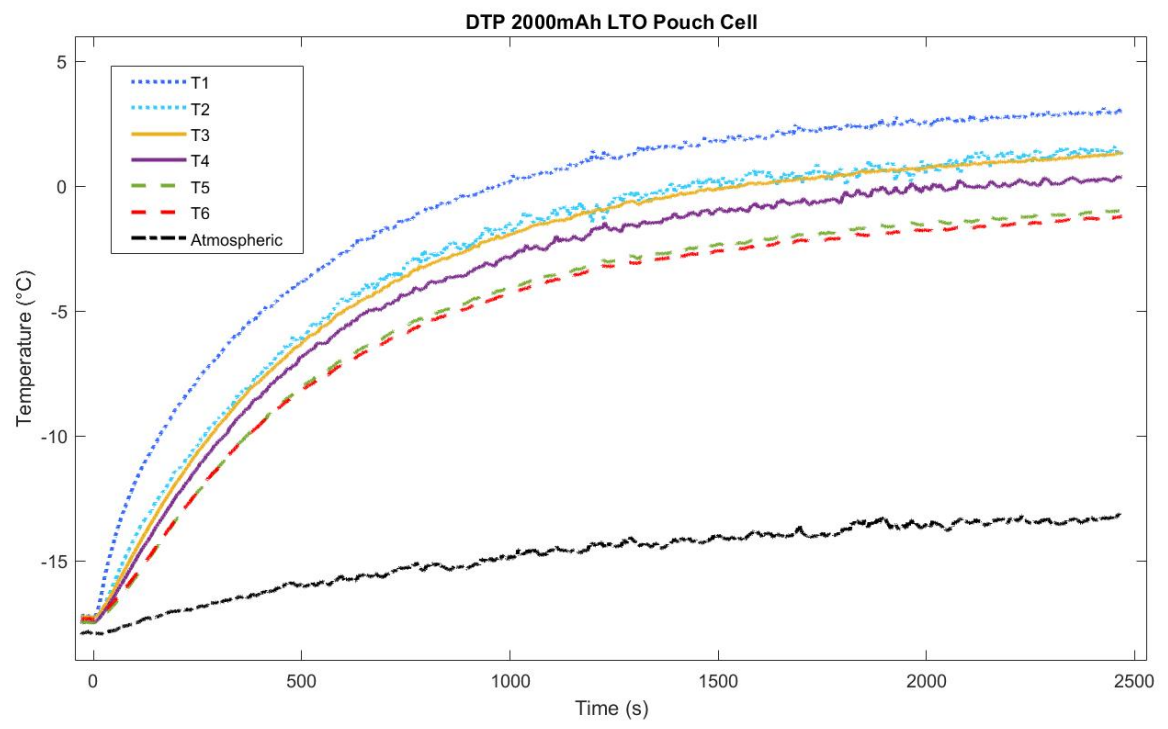

Figure 6. Temperature evolution of the $2000 \mathrm{mAh}$ pouch cell during the test. Temperatures T1-T6 correspond to the locations shown in Figure 3.

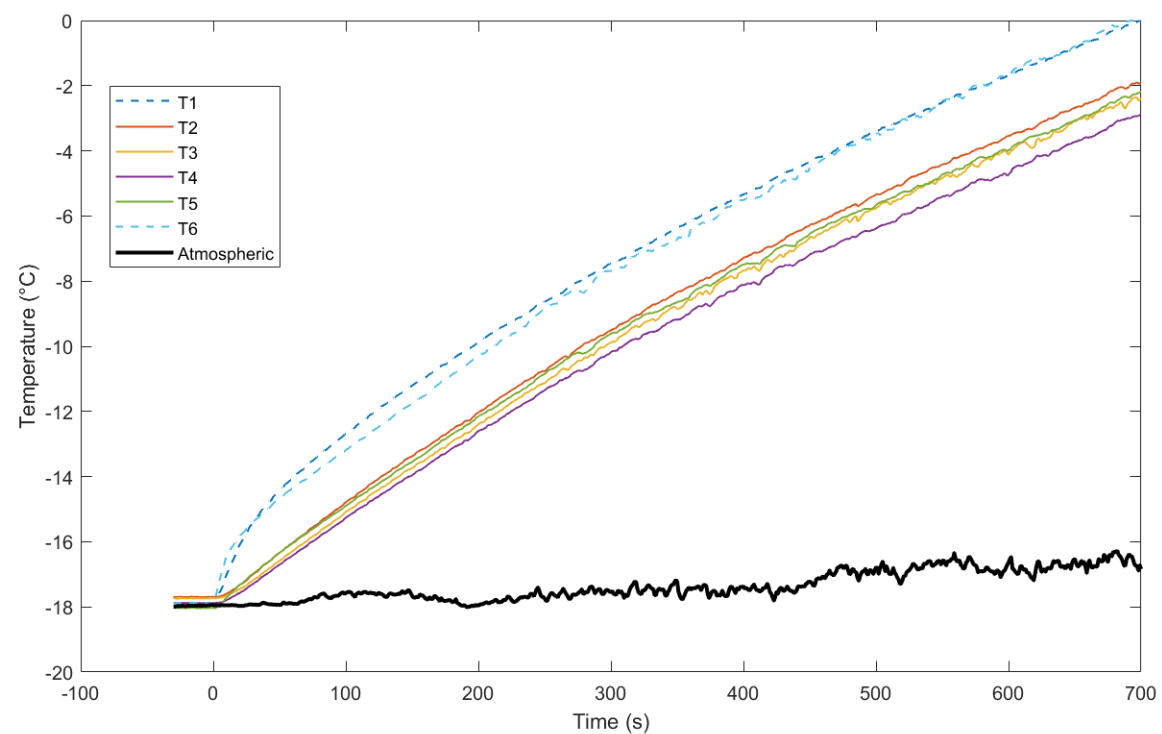

Figure 7. Temperature evolution of the Molicel 18650 battery cell during the test. Temperatures T1-T6 correspond to the locations shown in Figure 3.

For the 18650 cell, it can be seen in Figure 7 that the temperature measured at each end is higher than those in the middle of the cell, and the initial rate of heating is much 
higher and with less of a delay at the start of the test. The thermocouples at each end were still placed on the curved surface of the cell but were as close as possible to the end.

At the end of the test, the temperature profile along the axial direction of the 18650 cell is $U$ shaped, with the highest temperatures recorded on the ends and the lowest in the middle (Figure 8). This is likely due to the higher thermal conductivity of cylindrical cells in the axial rather than the radial direction [20], meaning that the ends reflect more closely the cell internal temperature, combined with the additional heating generated by the terminal connections (both internally and externally) at each end.

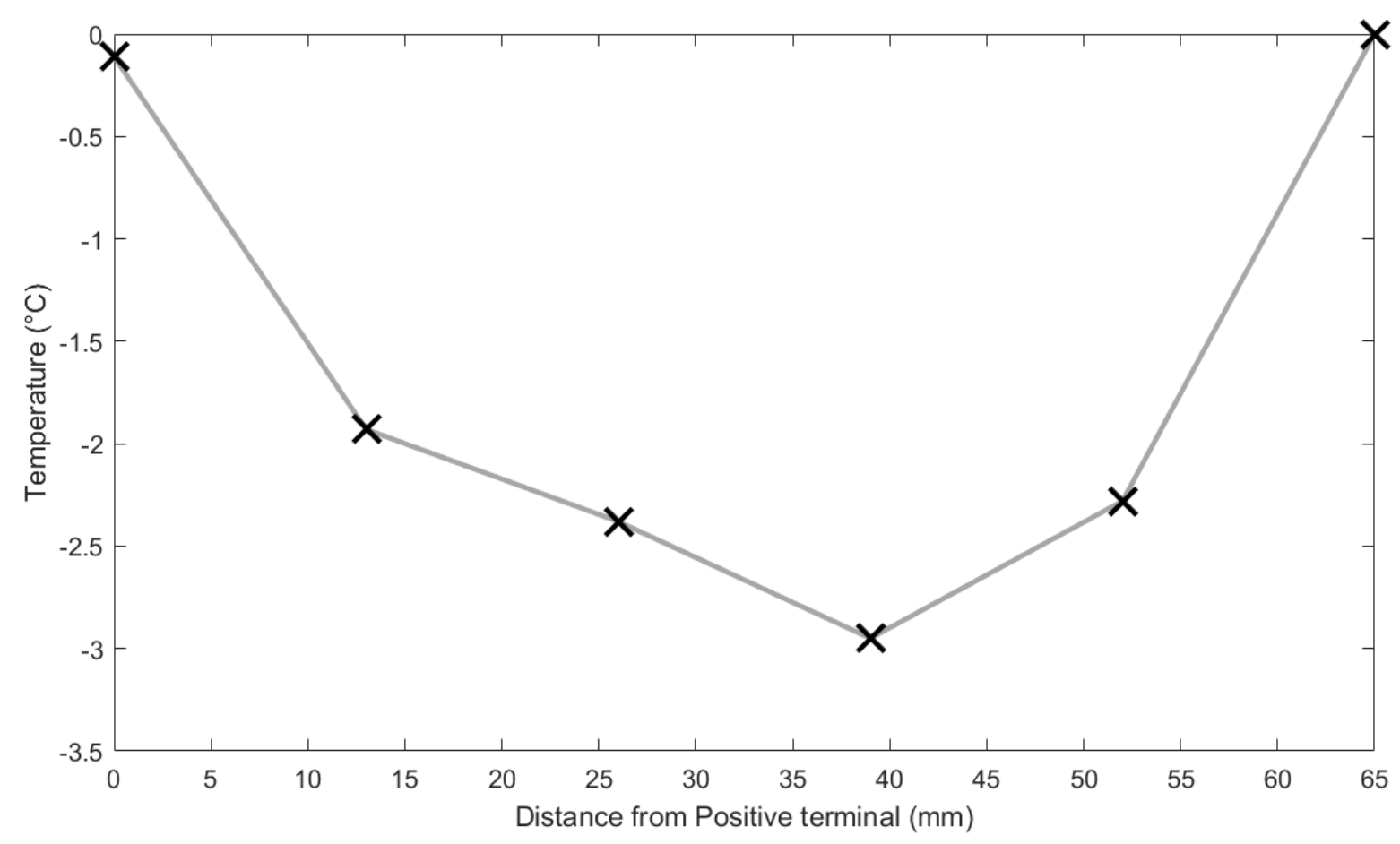

Figure 8. Temperature profile along the axial direction of the 18650 cell at the end of the test.

\section{Discussion}

\subsection{Effect of Cell Size on Heating Efficacy}

The results shown for the pouch cells in Figure 5 demonstrate an important aspect of the practicality of internal heating. From basic electrical theory, it follows that the total heat generation of the battery should be proportional to the square of the C-rate applied, and therefore for a given C-rate the heat generation per unit volume of battery is independent of the overall battery size. Nevertheless, the effectiveness of this heating also depends heavily on how quickly the battery loses the generated heat to its surroundings. This is shown clearly by the pouch cells in Figure 5, where the largest cell eventually reaches $0{ }^{\circ} \mathrm{C}$; however, the smaller cells reach less than $10^{\circ} \mathrm{C}$ over ambient before reaching thermal equilibrium.

For applications where cells are assembled into packs, this dependence on cell size is of far lesser concern, since adjacent cells will exchange heat with each other and reduce the SA exposed to the environment, being analogous from a heat transfer point of view to a single large cell. However, for individual cells or small modules with a high SA:V, this may be a practical limitation.

\subsection{Effect of Cell Type on Temperature Homogeinty}

The surface temperature inhomogeneity of the $2000 \mathrm{mAh}$ pouch cell is worse than the $2600 \mathrm{mAh}$ cylindrical cell by a factor of almost $50 \%$. This is an interesting observation, especially considering that the cylindrical cell achieves faster heating, and we posit several possible reasons for this. Firstly, the cylindrical cells have a steel casing which enables better 
heat spreading, whereas the pouch cells do not. Secondly, the terminal connections (tabs) are both at the top of the pouch cell, and it is well known that as charge is collected from the electrodes and transported to the connections the resulting increase in charge concentration $\left(\mathrm{A} / \mathrm{mm}^{2}\right)$ in the current collectors causes high losses in this area. The pouch cell, having both terminals adjacent to each other and in close proximity will suffer especially from this effect, whereas the cylindrical cell has terminals at opposite ends, to some extent 'balancing out' this effect. Importantly, just as a pouch cell with opposite-end tabs will perform much better than one with same-end tabs for temperature homogeneity during normal cycling [13,21], the importance of this is likely to be exaggerated for internal AC heating.

The increasing variation of cell temperature with increasing cell size is an important consideration when implementing internal $\mathrm{AC}$ heating. The potential for thermal gradients within cells should be evaluated since it could cause implementation and safety issues for internal heating. In particular, if cell temperatures were measured at a cold point, then the hottest part of the cell may exceed safe working limits. Temperature inhomogeneity also risks achieving suboptimal energy capacity, uneven depth of discharge, and generating uneven aging within cells. Further investigation is certainly needed to ascertain whether this trend continues with even larger batteries or other chemistries, and especially for automotive type cells which are tending towards ever larger formats ( $>60 \mathrm{Ah})$.

\section{Conclusions}

This paper has presented a novel method for applying a sinusoidal current signal to lithium-ion cells to cause internal heating from sub-zero temperatures. This method removes the need for complex and expensive battery cyclers when examining purely AC signals.

Battery internal heating was shown to be more effective for larger cells. This was demonstrated for both NMC cylindrical and Li-Po pouch cells and is due to the higher heat generation to surface area ratio (HG:SA) of larger batteries. Whilst the heat generated per unit volume is independent of battery size for a fixed C-rate, the heat lost to the environment is higher for small cells due to the proportionally higher surface area.

Contrastingly, cell size was also shown to have a negative effect on temperature homogeneity, with larger cells showing a larger variation in temperatures, through cell design and construction can have a key role to play in mitigating this. More research is required to ascertain whether this trend continues with even larger cells such as those used in automotive applications.

Author Contributions: Conceptualisation, H.R. and C.V.; methodology, H.R. and C.V.; investigation, H.R.; formal analysis, H.R.; resources, C.V.; data curation, H.R.; writing - original draft preparation, H.R. and C.V.; writing-review and editing, H.R. and C.V.; supervision, C.V.; project administration, C.V.; funding acquisition, C.V. All authors have read and agreed to the published version of the manuscript.

Funding: Howard Richards is supported by a scholarship from the EPSRC Centre for Doctoral Training in Advanced Automotive Propulsion Systems (AAPS), under the project EP/S023364/1. The APC was funded by the University of Bath.

Institutional Review Board Statement: Not applicable.

Informed Consent Statement: Not applicable.

Data Availability Statement: Not applicable.

Acknowledgments: The authors would like to acknowledge Frank Marken for the use of the Electrochemical Impedance Spectroscopy equipment used to measure the internal resistances of the cells.

Conflicts of Interest: The authors declare no conflict of interest. The funders had no role in the design of the study; in the collection, analyses, or interpretation of data; in the writing of the manuscript, or in the decision to publish the results. 


\section{References}

1. Armand, M.; Tarascon, J.M. Building Better Batteries. Nature 2008, 451, 652-657. [CrossRef]

2. Zhang, S.S.; Xu, K.; Jow, T.R. The low temperature performance of Li-ion batteries. J. Power Sources 2003, 115, 137-140. [CrossRef]

3. Babbitt, C.W. Sustainability perspectives on lithium-ion batteries. Clean Technol. Environ. Policy 2020, 22, 1213-1214. [CrossRef]

4. Mancini, L.; Eslava, N.A.; Traverso, M.; Mathieux, F. Assessing impacts of responsible sourcing initiatives for cobalt: Insights from a case study. Resour. Policy 2021, 71, 102015. [CrossRef]

5. Kwik-Fit. Available online: https://www.kwik-fit.com/press/pandemic-has-caused-almost-14-million-uk-drivers-to-changetheir-car-buying-plans (accessed on 10 November 2021).

6. Ji, Y.; Wang, C.Y. Heating strategies for Li-ion batteries operated from subzero temperatures. Electrochim. Acta 2013, 107, 664-674. [CrossRef]

7. Hu, X.; Zheng, Y.; Howey, D.A.; Perez, H.; Foley, A.; Pecht, M. Battery warm-up methodologies at subzero temperatures for automotive applications: Recent advances and perspectives. Prog. Energy Combust. Sci. 2020, 77, 1000806. [CrossRef]

8. Peng, X.; Chen, S.; Garg, A.; Bao, N.; Panda, B. A review of the estimation and heating methods for lithium-ion batteries pack at the cold environment. Energy Sci. Eng. 2019, 7, 645-662.

9. Ruan, H.; Jiang, J.; Sun, B.; Su, X.; He, X.; Zhao, K. An optimal internal-heating strategy for lithium-ion batteries at low temperature considering both heating time and lifetime reduction. Appl. Energy 2019, 256, 113797.

10. Mohan, S.; Siegel, J.B.; Stefanopoulou, A.G.; Vasudevan, R. An Energy-Optimal Warm-Up Strategy for Li-Ion Batteries and Its Approximations. IEEE Trans. Control. Sys. Tech. 2019, 27, 1165-1180. [CrossRef]

11. Ruan, H.; Jiang, J.; Sun, B.; Zhang, W.; Gao, W.; Wang, L.Y.; Ma, Z. A rapid low-temperature internal heating strategy with optimal frequency based on constant polarization voltage for lithium-ion batteries. Appl. Energy 2016, 177, 771-782. [CrossRef]

12. Zhu, J.; Sun, Z.; Wei, X.; Dai, H.; Gu, W. Experimental investigations of an AC pulse heating method for vehicular high power lithium-ion batteries at subzero temperatures. J. Power Sources 2017, 367, 145-157. [CrossRef]

13. Rizk, R.; Louahlia, H.; Gualous, H.; Schaetzel, P.; Alcicek, G. Experimental analysis on Li-ion battery local heat distribution. J. Therm. Anal. Calorim. 2019, 138, 1557-1571. [CrossRef]

14. Jiang, J.; Ruan, H.; Sun, B.; Wang, L.; Gao, W.; Zhang, W. A low-temperature internal heating strategy without lifetime reduction for large-size automotive lithium-ion battery pack. Appl. Energy 2018, 230, 257-266. [CrossRef]

15. Ge, H.; Huang, J.; Zhang, J.; Li, Z. Temperature-Adaptive Alternating Current Preheating of Lithium-Ion Batteries with Lithium Deposition Prevention. J. Electrochem. Soc. 2015, 163, A290-A299. [CrossRef]

16. Uddin, K.; Moore, A.D.; Barai, A.; Marco, J. The effects of high frequency current ripple on electric vehicle battery performance. Appl. Energy 2016, 178, 142-154. [CrossRef]

17. Shang, Y.; Liu, K.; Cui, N.; Zhang, Q.; Zhang, C. A Sine-Wave Heating Circuit for Automotive Battery Self-Heating at Subzero Temperatures. IEEE Trans. Inustr. Inform. 2020, 16, 3355-3365. [CrossRef]

18. Shang, Y.; Liu, K.; Cui, N.; Wang, N.; Li, K.; Zhang, C. A Compact Resonant Switched-Capacitor Heater for Lithium-Ion Battery Self-Heating at Low Temperatures. IEEE Trans. Power Electron. 2020, 35, 7134-7144. [CrossRef]

19. Venkateshan, S.P. Introduction to the Study of Heat Transfer. In Heat Transfer, 3rd ed.; Springer: Cham, Switzerland, $2021 ;$ p. 14.

20. Samba, A.; Omar, N.; Gualous, H.; Capron, O.; Van den Bossche, P.; Van Mierlo, J. Impact of Tab Location on Large Format Lithium-Ion Pouch Cell Based on Fully Coupled Tree-Dimensional Electrochemical-Thermal Modeling. Electrochim. Acta 2014, 147, 319-329. [CrossRef]

21. Drake, S.J.; Wetz, D.A.; Ostanek, J.K.; Miller, S.P.; Heinzel, J.M.; Jain, A. Measurement of anisotropic thermophysical properties of cylindrical Li-ion cells. J. Power Sources 2014, 252, 298-304. [CrossRef] 